\title{
Pengaruh Kinerja Keuangan terhadap Kemampuan Membayar Zakat PT. BRI Syariah Periode 2011-2018
}

\author{
Budi Yanti Ritonga ${ }^{1}$, Budi Gautama Siregar², Windari3 \\ 1,2,3Institut Agama Islam Negeri Padangsidimpuan \\ JL. H.T. Rizal Nurdin Km 4,5 Sihitang Kota Padangsidimpuan - Sumatera Utara \\ Email: windari@iain-padangsidimpuan.ac.id
}

\begin{abstract}
Abstrak
Lembaga keuangan syariah termasuk PT. BRI Syariah dari laporan keuangan ditentukan besarnya zakat perusahaan sebab dalam Islam salah satu tujuan pelaporan keuangan adalah untuk keperluan zakat. Penelitian ini adalah penelitian kuantitatif. Teknik pengumpulan yang digunakan dalam penelitian ini adalah data sekunder sebanyak 32 sampel. Teknik pengumpulan data adalah dokumentasi. Teknik analisis data menggunakan metode regresi linear berganda, uji asumsi klasik, dan uji hipotesis dengan pengolahan data menggunakan program komputer SPSS versi 23. Hasil penelitian secara parsial (uji t) menyatakan bahwa, ROA berpengaruh signifikan terhadap kemampuan membayar zakat. ROE memiliki berpengaruh negatif signifikan terhadap kemampuan membayar zakat. BOPO berpengaruh negatif signifikan terhadap kemampuan membayar zakat. Hasil penelitian secara simultan (uji F) menyatakan bahwa ROA, ROE dan BOPO berpengaruh terhadap kemampuan membayar zakat. Sedangkan hasil koefisien determinasi $\left(\mathrm{R}^{2}\right) \mathrm{ROA}$, ROE dan BOPO mampu memengaruhi kemampuan membayar zakat.
\end{abstract}

Kata kunci: ROA, ROE, BOPO, Kemampuan Membayar Zakat

\begin{abstract}
Islamic financial institutions including PT. BRI Syariah from the financial statements determines the amount of zakat of the company because in Islam one of the objectives of financial reporting is for the purposes of zakat. This research is a quantitative research. The collection technique used in this study was secondary data as many as 32 samples. The data collection technique is documentation. The data analysis technique used multiple linear regression methods, classical assumption tests, and hypothesis testing with data processing using the SPSS version 23 computer program. The results of the study partially ( $t$ test) stated that, ROA had a significant effect on the ability to pay zakat. ROE has a significant negative effect on the ability to pay zakat. BOPO has a significant negative effect on the ability to pay zakat. Simultaneous research results ( $F$ test) states that $R O A, R O E$ and BOPO affect the ability to pay zakat. While the results of the coefficient of determination (R2) ROA, ROE and BOPO are able to influence the ability to pay zakat.
\end{abstract}

Keywords: ROA, ROE, BOPO, Ability to Pay Zakat 
249 | Pengaruh Kinerja Keuangan Terhadap Kemampuan Membayar Zakat PT. BRI Syariah Periode 2011 - 2018

\section{PENDAHULUAN}

Zakat menurut Undang-Undang No. 23 Tahun 2011 pasal 1 ayat 2 adalah harta yang wajib dikeluarkan oleh seorang muslim atau badan usaha untuk diberikan kepada yang berhak menerimanya sesuai dengan syariat Islam (Tim Fokusmedia, 2012). Zakat adalah sebagian harta yang wajib dikeluarkan oleh wajib zakat (muzakki) untuk diserahkan kepada penerima zakat (mustahiq). Pembayaran zakat dilakukan apabila nisab dan haulnya terpenuhi dari harta yang memenuhi kriteria wajib zakat.

Penelitian ini hanya membahas zakat yang dikeluarkan pihak BRI Syariah sebagai mana yang telah ditetapkan perhitungan zakat perusahaan didasarkan pada laporan keuangan dengan mengurangkan kewajiban atas aktiva lancar atau dikurangi pembayaran utang dan kewajiban lainnya, zakat yang wajib dikeluarkan adalah 2,5\% (2,5\% dari laba sebelum pajak) (Hafidhuddin, 2002). Untuk mengetahui perhitungan dana zakat dan kinerja bank diperlukan adanya laporan keuangan secara umum yang sudah berlaku. Laporan keuangan menyajikan hal-hal penting dari perusahaan yang berupa kinerja keuangan bank. Dari kinerja keuangan tersebut dapat diketahui jumlah zakat yang dikeluarkan bank syariah. Berikut ini tabel kemampuan membayar zakat pada PT. BRI Syariah.

\section{Tabel 1}

Kemampuan membayar zakat PT. BRI Syariah

\begin{tabular}{|c|c|}
\hline Tahun & $\begin{array}{c}\text { Kemampuan } \\
\text { Membayar Zakat }\end{array}$ \\
\hline 2011 & 1.982 .000 .000 \\
\hline 2012 & 3.363 .000 .000 \\
\hline 2013 & 5.615 .000 .000 \\
\hline 2014 & 7.080 .000 .000 \\
\hline 2015 & 4.242 .000 .000 \\
\hline 2016 & 6.998 .000 .000 \\
\hline 2017 & 8.933 .000 .000 \\
\hline 2018 & 7.051 .000 .000 \\
\hline
\end{tabular}

Sumber: Laporan Tahunan BRI Syariah (www.brisyariah.co.id)

Berdasarkan tabel diatas dapat dilihat bahwa kemampuan membayar zakat rata-rata mengalami peningkatan. Namun pada tahun 2015 mengalami penurunan sebesar 40,06\% dari tahun sebelumnya. Hal yang sama terjadi pada tahun 2018 yang mengalami penurunan sebesar 21,06\%.

Berdasarkan penelitian yang juga dilakukan oleh Winda Tri Jayanti, Siti Khairani, Raisa Pratiwi yang berjudul "Pengaruh Kinerja Keuangan Terhadap Zakat Bank Umum Syariah yang Terdaftar di Indinesia Periode 2010-2014" menyatakan dalam penelitiannya bahwa kinerja keuangan (ROA dan ROE) berpengaruh terhadap zakat, BOPO dan NIM tidak berpengaruh terhadap zakat (Tri Jayanti et al., n.d.). Berdasarkan juga penelitian yang dilakukan oleh Fitria Liana yang berjudul "Pengaruh Prpfitabilitas Terhadap Peneluaran Zakat Perusahaan (Studi Kasus Pada Bank Umum Syariah Di Indonesia Periode 2012-2016)” JISFIM: Journal of Islamic Social Finance Management, Volume 1, No 2 Tahun 2020 http://jurnal.iain-padangsidimpuan.ac.id/index.php/JISFIM 
menyatakan bahwa ROA, ROE, NOM, dan BOPO berpengaruh positif signifikan terhadap variabel defenden yaitu zakat perusahaan (Liana, 2018). Dari hasil uraian diatas maka peneliti tertarik untuk meneliti kinerja keuangan terhadap kemampuan membayar zakat. Maka peneliti membuat penelitian dengan judul "Pengaruh Kinerja Keuangan Terhadap Kemampuan Membayar Zakat PT. BRI Syariah Periode 2011-2018”.

\section{KAJIAN TEORITIS}

\section{Pengertian Zakat}

Secara etimologi zakat mempunyai makna pensucian, pertumbuhan, dan berkah. Sedangkan secara terminology zakat adalah kewajiban seorang muslim untuk mengeluarkan nilai bersih dari kekayaan yang tidak melebihi satu nisab, diberikan kepada mustahiq dengan beberapa syarat yang telah ditentukan.

Zakat merupakan jalinan persekutuan antara yang kaya dan yang miskin. Melalui zakat, persekutuan tersebut diperbaharui setiap tahun, terus menerus. Oleh karena itu, zakat seharusnya dapat mengambil peranan signifikan dalam kesejahteraan sosial. Zakat merupakan instrumen religius yang membantu perseorangan dalam masyarakat untuk menolong penduduk muslim yang tidak mampu menolong dirinya sendiri agar kemiskinan dan kesengsaraan hilang dari masyarakat (muslim) (Khasanah, 2010).

Ditinjau dari ekonomi Islam, zakat sebagai salah satu instrumen fiskal untuk mencapai tujuan keadilan sosial ekonomi dan distribusi kekayaan dan pendapatan, secara aklamasi dipandang sebagai bagian tak terpisahkan dari falsafah moral Islam dan didasarkan pada komitmen yang pasti terhadap persaudaraan kemanusiaan. Ditinjau dari perspektif ekonomi, zakat merupakan push factor bagi perbaikan kondisi masyarakat, khususnya perbaikan ekonomi, karena dengan adanya distribusi zakat akan terjadi pertumbuhan kesejahteraan masyarakat dalam arti yang lebih luas. Zakat merupakan salah satu sumber keuangan berdasarkan asas keadilan dan perpaduan antara kepentingan umum dan kepentingan pemilik harta.

Zakat menurut Undang-Undang No. 23 Tahun 2011 pasal 1 ayat 2 adalah harta yang wajib dikeluarkan oleh seorang muslim atau badan usaha untuk diberikan kepada yang berhak menerimanya sesuai dengan syariat Islam (Tim Fokusmedia, 2012). Zakat adalah kewajiban berdasarkan syariat. Islam mewajibkannya atas setiap muslim yang sampai padanya nishab (batas minimal dari harta mulai wajib dikeluarkan) zakatnya. Zakat adalah salah satu rukun Islam, bahkan merupakan rukun kemasyarakatan yang paling tampak diantara sekalian rukun-rukun Islam. Sebab zakat adalah hak orang banyak yang terpikul pada undak individu. Dinamakan zakat, karena ia mensucikan jiwa dan masyarakat. Zakat membersihkan atau mensucikan jiwa dari sifat kikir dan bakhil. 


\section{1 | Pengaruh Kinerja Keuangan Terhadap Kemampuan Membayar Zakat PT. BRI Syariah Periode 2011 - 2018}

Rukun zakat ialah mengeluarkan sebagian dari nishab (harta) dengan melepaskan kepemilikan terhadapnya, menjadikannya sebagai milik orang fakir, dan menyerahkannya kepadanya atau harta tersebut diserahkan kepada wakilnya, yakni imam atau orang yang bertugas untuk memungut zakat.

Adapun syarat wajib zakat, yakni kefarduannya, ialah sebagai berikut (Al-Zuhayly, 2000):

1. Merdeka.

2. Islam.

3. Baligh dan berakal.

4. Harta yang dikeluarkan adalah harta yang wajib dizakati.

5. Harta yang dizakati telah mencapai nishab atau senilai dengannya.

6. Harta yang dizakati adalah milik penuh.

7. Kepemilikan harta telah mencapai setahun, menurut hitungan tahun qamariyah.

8. Harta tersebut bukan merupakan harta hasil hutang.

\section{a. Zakat Perusahaan}

\section{1) Pengertian Zakat Perusahaan}

Zakat perusahaan adalah zakat yang didasarkan atas prinsip keadilan serta hasil ijtihad para ahli fikih. Kewajiban zakat perusahaan hanya ditujukan kepada perusahaan yang dimiliki oleh muslim. Sehingga zakat ini tidak ditujukan pada harta perusahaan yang tidak dimiliki oleh muslim.

Para ulama kontemporer menganalogikan zakat perusahaan kepada zakat perdagangan, karena dipandang dari aspek legal dan ekonomi, kegiatan sebuah perusahaan intinya berpijak pada kegiatan trading atau perdagangan, hal tersebut dikatakan oleh keputusan seminar I zakat di Kuwait, tanggal 3 April 1984 tentang zakat perusahaan.

Zakat perusahaan harus dikeluarkan jika syarat berikut terpenuhi:

1. Kepemilikan dikuasai oleh muslim/muslimin.

2. Bidang usaha harus halal

3. Aset perusahaan dapat dinilai

4. Aset perusahaan dapat berkembang

5. Minimal kekayaan perusahaan setara dengan 85 gram emas

Sedangkan syarat teknisnya adalah sebagai berikut:

1. Adanya peraturan yang mengharuskan pembayaran zakat perusahaan tersebut.

2. Anggaran dasar perusahaan memuat hal tersebut.

3. RUPS mengeluarkan keputusan yang berkaitan dengan hal itu.

4. Kerelaan para pemegang saham menyerahkan pengeluaran zakat sahamnya kepada dewan direksi perusaan.

JISFIM: Journal of Islamic Social Finance Management, Volume 1, No 2 Tahun 2020 http://jurnal.iain-padangsidimpuan.ac.id/index.php/JISFIM 
Idealnya perusahaan yang bersangkutan itulah yang membayar zakat jika memenuhi kondisi yang disebutkan diatas. Jika tidak, maka perusahaan harus menghitung seluruh zakat kekayaannya kemudian memasukkan ke dalam anggaran tahutan sebagai catatan yang menerangkan nilai zakat setiap saham mempermudah pemegang saham mengetahui berapa zakat sahamnya (fatwa zakat kontemporer) (Nurhayati, 2014).

Landasan hukum dalam kaitan kewajiban zakat perusahaan ini, terdapat dalam Undang-Undang No. 23 Tahun 2011, tentang Pengelolaan Zakat, Bab IV pasal 11 ayat (2) bagian (b) dikemukakan bahwa di antara yang objek zakat yang wajib dikeluarkan zakatnya adalah perdagangan dan perusahaan.

Landasan hukum agama Islam kewajiban zakat pada perusahaan adalah nash-nash yang bersifat umum, seperti firman Allah SWT dalam Surah AtTaubah ayat 103

Artinya: Ambillah zakat dari sebagian harta mereka, dengan zakat itu kamu membersihkan dan mensucikan mereka dan berdoalah untuk mereka. Sesungguhnya doa kamu itu (menjadi) ketenteraman jiwa bagi mereka. dan Allah Maha mendengar lagi Maha mengetahui (Departemen Agama RI, 2014).

Tafsir ayat ini menjelaskan tentang sekelompok orang yang imannya masih lemah, yang mencampurbaurkan amal baik dan buruk dalam kegiatannya. Mereka diharapkan dapat diampuni Allah. Salah satu cara pengampunan-Nya adalah melalui sedekah dan pembayaran zakat. Karena itu, disini Nabi Muhammad Saw. diperintah: Ambillah atas nama Allah sedekah, yakni harta berupa zakat dan sedekah, yang hendaknya mereka serahkan dengan penuh kesungguhan dan ketulusan hati, dari sebagian harta mereka, bukan seluruhnya, bukan pula sebagian besar, dan tidak juga yang terbaik; dengannya, yakni dengan harta yang engkau ambil itu, engkau membersihkan harta dan jiwa mereka dan menyucikan jiwa lagi mengembangkan harta mereka, dan berdoalah untuk mereka guna menunjukkan restumu terhadap mereka dan memohonlah keselamatan dan kesejahteraan bagi mereka. Sesungguhnya doamu itu adalah sesuatu yang dapat menjadi ketentraman jiwa bagi mereka yang selama ini gelisah dan takut akibat dosa-dosa yang mereka lakukan. Dan sampaikanlah kepada mereka bahwa Allah Maha Mendengar lagi Maha Mengetahui (Shihab, 2002). http://jurnal.iain-padangsidimpuan.ac.id/index.php/JISFIM 


\section{b) Batasan atau Nisab Zakat dan Perhitungan Zakat Perusahaan}

Sebagai suatu kewajiban yang khas dalam agama Islam, zakat dukeluarkan setelah mencapai batas minimal atas kewajiban yang dikeluarkan. Dengan kata lain, zakat dikeluarkan atas harta yang dimiliki oleh seseorang. Harta dalam Islam dapatb menggolongkan pemiliknya ke dalam golongan orang-orang kaya menurut pengertian zakat, manakala telah memenuhi dua syarat, yaitu: pertama, harta itu telah sampai batas minimal yang diistilahkan dengan nishab. Batas minimal ini diperkirakan untuk barang-barang komoditi seharga 20 dinar emas. Adapun untuk hasil-hasil pertanian, jumhur fuqaha (kebanyakan ahli hukum Islam) berpendapat bahwa setiap tetumbuhan bumi yang ada zakatnya, tidak ada nisabnya yang tertentu. Kedua, pemilik harta tetap memiliki senisab ini dalam masa satu tahun penuh, selebihnya dari kebutuhan-kebutuhannya yang asli seperti tempat tinggal, makanan dan pakaian.

Zakat perusahaan pada umumnya dianalogikan pada zakat perdangan hal tersebut sesuai dengan pendapat Muktamar Zakat Internasional, karena dipandang dari aspek legal dan ekonomi kegiatan sebuah perusahaan intinya berpijak pada kegiatan trading atau perdagangan. Oleh karena itu, secara umum pola pembayaran dan perhitungan zakat perusahaan adalah sama dengan zakat perdagangan. Demikian nishabnya adalah 85 gram emas murni, perhitungan zakat perusahaan didasarkan pada laporan keuangan (neraca) dengan mengurangkan kewajiban atas aktiva lancar atau dikurangi pembayaran utang dan kewajiban lainnya, zakat yang wajib dikeluarkan adalah $2,5 \%$ oleh perusahaan (Hafidhuddin, 2002).

\section{Hubungan Return On Equity (ROE) terhadap Kemampuan Membayar Zakat}

Rasio Return On Equity (ROE) ini merupakan indikator yang sangat sering digunakan bagi calon investor dan para pemegang saham untuk mengetahui dan menilai tingkat kemampuan bank mendapatkan keuntungan bersih yang dikaitkan dengan pembayaran deviden. Peningkatan dalam rasio ini berarti terjadinya peningkatan keuntungan bersih dari bank yang bersangkutan. Menurut Triwuyono, melalui zakat dapat diketahui kinerja perusahaan yaitu semakin tinggi zakat yang dikeluarkan oleh perusahaan berarti semakin besar laba yang di dapat perusahaan (Muhamad, 2008).

Hasil penelitian yang dilakukan oleh Ahmad Nurul Muammar memberikan hasil bahwa Return On Equity (ROE) berpengaruh positif signifikan terhadap zakat JISFIM: Journal of Islamic Social Finance Management, Volume 1, No 2 Tahun 2020 http://jurnal.iain-padangsidimpuan.ac.id/index.php/JISFIM 
(Muammar, 2010). Berdasarkan teori dan bukti empiris tentang pengaruh Return On Equity (ROE) terhadap kemampuan membayar zakat, maka dapat disimpulkan bahwa Return On Equity (ROE) berpengaruh terhadap kemampuan membayar zakat

\section{Hubungan Biaya Operasional per Pendapatan Operasional (BOPO) terhadap Kemampuan Membayar Zakat}

Rasio Biaya Operasional per Pendapatan Operasional (BOPO) ini digunakan untuk mengetahui dan menilai tingkat efesiensi dan kemampuan bank dalam melaksanakan aktivitas operasinya. Jika Biaya Operasional per Pendapatan Operasional (BOPO) semakin meningkat maka kinerja manajemen perusahaan semakin menurun, karena BOPO mengurangi pendapatan suatu perusahaan. Sehingga dapat ditarik kesimpulan semakin rendah tingkat rasio BOPO berarti pengeluaran zakat semakin menurun (Sukmawati, 2018).

Hasil penelitian yang diteliti oleh Enggardini Sukmawati mendapatkan hasil bahwa Biaya Operasional per Pendapatan Operasional (BOPO) berpengaruh negatif terhadap variabel defenden yaitu kemampuan zakat (Sukmawati, 2018). Berdasarkan teori dan bukti empiris maka dapat disimpulkan bahwa Biaya Operasional per Pendapatan Operasional (BOPO) berpengaruh terhadap kemampuan membayar zakat.

\section{METODE PENELITIAN}

Penelitian ini dilakukan pada PT. BRI Syariah seluruh Indonesia melalui situs resmi PT. BRI Syariah (www.brisyariah.co.id). Penelitian ini dilakukan mulai dari bulan April 2019 sampai dengan Desember 2019. Jenis penelitian yang digunakan adalah kuantitatif yang bermaksud menggambarkan fenomena pada obyek penelitian apa adanya dan pengambilan kesimpulan didasarkan pada angka-angka hasil analisis statistik. Dilihat dari permasalahan yang diteliti, penelitian ini bersifat asosiatif, yaitu penelitian yang bertujuan untuk mengetahui pengaruh ataupun juga hubungan antara dua variabel atau lebih (Sukmawati, 2018).

Data ini merupakan data yang menurut dimensi waktu (data runtun waktu/time series), yaitu data yang secara kronologis disusun menurut waktu pada satu variabel tertentu. Data runtun waktu digunakan untuk melihat pengaruh perubahan dalam rentang waktu tertentu, variasi terjadinya variabel adalah antara waktu (Kuncoro, 2009). Data tersebut diperoleh dari laporan keuangan PT. BRI Syariah yang dipublikasikan oleh PT. BRI Syariah. Sampel adalah bagian dari jumlah dan karakteristik yang dimiliki oleh populasi tersebut. Bila populasi besar, dan peneliti tidak mungkin mempelajari semua yang ada pada populasi, misalnya karena keterbatasan dana, tenaga dan waktu, maka peneliti dapat menggunakan sampel yang diambil dari populasi itu. Adapun Teknik sampel yang http://jurnal.iain-padangsidimpuan.ac.id/index.php/JISFIM 


\section{5 | Pengaruh Kinerja Keuangan Terhadap Kemampuan Membayar Zakat PT. BRI Syariah Periode 2011 - 2018}

digunakan adalah sampel jenuh. Sampel jenuh adalah teknik pengumpulan sampel bila semua anggota populasi digunakan sebagai sampel. Berdasarkan pengertian sampel di atas, maka yang menjadi sampel pada penelitian ini adalah ROA, ROE, BOPO dan Zakat pada laporan keuangan triwulan PT BRI Syariah yang dipublikasikan oleh Otoritas Jasa Keuangan (OJK) melalui website $\underline{w w w . o j k . g o . i d}$ periode 2011-2018 yaitu sebanyak 32 sampel.

Sebuah data terkumpul dari hasil pengumpulan data. Maka akan dilakukan analisis data atau pengolahan data. Metode analisis data yang digunakan adalah metode SPSS Versi 23. Dengan Uji Asumsi Klasik berupa: Uji Normalitas dimana Uji normalitas yang digunakan adalah dengan metode uji one sample kolmogrov smirnov dan metode grafik. Untuk melihat apakah regresi data normal adalah jika nilai-nilai $\mathrm{p} \geq 0,05$ maka distribusi data dinyatakan memenuhi asumsi normalitas, dan jika nilainya $\mathrm{p} \leq 0,05$ maka iinterpretasikan sebagai tidak normal. Lalu, Uji Multikolinieritas dimana persyaratan yang harus dipenuhi dalam model regresi adalah tidak adanya multikilinearitas. Suatu model regresi dinyatakan bebas dari multikolonieritas adalah jika nilai Variance Inflation Factor VIF $<10$ dan nilai tolerance $>$ 0,1 (Setiawan, 2019). Selanjutnya, Uji Autokolerasi dan Uji Heteroskedastisitas. Lalu dilakukan Uji Hipotesis yang terdiri dari Uji Koefisien Regresi secara Parsial (Uji t) dan Uji Signifikan Simultan (Uji F) serta Uji Koefesien Determinasi R Square $\left(\mathrm{R}^{2}\right)$. Selanjutnya dilakukan Analisis Regresi Berganda

Adapun bentuk persamaan regresi linear berganda yang digunakan dalam penelitian ini sebagai berikut:

$$
\mathrm{Y}=\mathrm{a}+\mathrm{b}_{1} \mathrm{X}_{1}+\mathrm{b}_{2} \mathrm{X}_{2}+\mathrm{e}
$$

Atau

$$
\mathrm{ZK}_{\mathrm{i}}=\mathrm{a}+\mathrm{b}_{1} \mathrm{ROA}_{\mathrm{i}}+\mathrm{b}_{2} \mathrm{ROE}_{\mathrm{i}}+\mathrm{b}_{3} \mathrm{BOPO}_{\mathrm{i}}+\mathrm{e}
$$

Keterangan:

$\begin{array}{ll}\text { ZK } & \text { : Zakat } \\ \mathrm{a} & \text { : Konstanta } \\ \mathrm{b}_{1} \mathrm{~b}_{2} & \text { : Koefisien regresi } \\ \mathrm{ROA} & : \text { Return On Asset } \\ \mathrm{ROE} & : \text { Return On Equity } \\ \text { BOPO } & \text { : Biaya Operasional dan Pendapatan Operasional } \\ \mathrm{e} & \text { : error } \\ \mathrm{i} & \text { : Estimasi }\end{array}$

JISFIM: Journal of Islamic Social Finance Management, Volume 1, No 2 Tahun 2020 http://jurnal.iain-padangsidimpuan.ac.id/index.php/JISFIM 


\section{HASIL DAN PEMBAHASAN}

Dalam penelitian ini, peneliti memperoleh data dari laporan keuangan publikasi pada PT. Bank Rakyat Indonesia Syariah dari situs resmi www.ojk.go.id.

1. Kemampuan Membayar Zakat

Zakat adalah kewajiban seorang muslim untuk mengeluarkan nilai bersih dari kekayaan yang tidak melebihi satu nisab, diberikan kepada mustahiq dengan beberapa syarat yang telah ditentukan. Ditinjau dari ekonomi Islam, zakat sebagai salah satu instrumen fiskal untuk mencapai tujuan keadilan sosial ekonomi dan distribusi kekayaan dan pendapatan, secara aklamasi dipandang sebagai bagian tak terpisahkan dari falsafah moral Islam dan didasarkan pada komitmen yang pasti terhadap persaudaraan kemanusiaan.

Secara umum pola pembayaran dan perhitungan zakat perusahaan adalah sama dengan zakat perdagangan. Demikian nishabnya adalah 85 gram emas murni, perhitungan zakat perusahaan didasarkan pada laporan keuangan (neraca) dengan mengurangkan kewajiban atas aktiva lancar atau dikurangi pembayaran utang dan kewajiban lainnya, zakat yang wajib dikeluarkan adalah 2,5\% oleh perusahaan.

Tabel 2

Kemampuan Membayar Zakat PT. BRI Syariah Periode 2011-2018 (dalam jutaan rupiah)

\begin{tabular}{|c|c|c|c|c|}
\hline \multirow{2}{*}{ Tahun } & \multicolumn{4}{|c|}{ Triwulan } \\
\cline { 2 - 5 } & I & II & III & IV \\
\hline 2011 & 100,175 & 185,425 & 582,9 & 417,525 \\
\hline 2012 & 114,85 & 1628,425 & 2789,875 & 3451,3 \\
\hline 2013 & 1520,175 & 2622,525 & 4041,175 & 4598,55 \\
\hline 2014 & 501,625 & 59,6 & 656,275 & 384,625 \\
\hline 2015 & 632,3 & 1503,8 & 2327,875 & 3065,925 \\
\hline 2016 & 1461,3 & 3114,95 & 4370,25 & 4255,225 \\
\hline 2017 & 829,425 & 1766,425 & 3182,475 & 2527,275 \\
\hline 2018 & 1359,525 & 3003,925 & 3778,7 & 2665 \\
\hline
\end{tabular}

Sumber: www.ojk.go.id

Berdasarkan tabel diatas dapat dilihat bahwa kemampuan membayar zakat berfluktuasi. kemampuan membayar zakat PT. BRI Syariah paling rendah terjadi pada 2014 pada triwulan II sebesar Rp. 59.600.000 atau mengalami penurunan sebesar Rp. 442.025.000 dari tahun sebelumnya. Sedangkan kemampuan membayar zakat tertinggi terjadi pada tahun 2013 triwulan ke IV sebesar Rp. 4.598.550.00o dari tahun sebelumnya.

2. Return On Asset (ROA)

Return On Asset (ROA) adalah rasio yang digunakan untuk mengukur kemampuan manajemen bank dalam memperoleh keuntungan (laba sebelum pajak) yang dihasilkan dari rata-rata total aset bank yang bersangkutan. Semakin besar JISFIM: Journal of Islamic Social Finance Management, Volume 1, No 2 Tahun 2020 http://jurnal.iain-padangsidimpuan.ac.id/index.php/JISFIM 
257 | Pengaruh Kinerja Keuangan Terhadap Kemampuan Membayar Zakat PT. BRI Syariah Periode 2011 - 2018

Return On Asset (ROA), semakin besar pula tingkat keuntunga yang dicapai bank sehingga kemungkinan suatu bank dalam kondisi bermasalah semakin kecil.

Jadi Return On Asset (ROA) merupakan rasio yang menunjukkan hubungan antara tingkat keuntungan yang dihasilkan manajemen atas dana yang ditanam baik oleh pemegang saham, maupun kreditor. Rasio ini menggambarkan kemampuan aktiva perusahaan dalam menghasilkan laba. Semakin besar Return On Asset (ROA) suatu bank, maka akan semakin besar tingkat keuntungan bank dan semakin baik pula posisi bank dalam penggunaan aset.

Tabel 3

Return On Asset (ROA) Periode 2011-2018

(dalam persen)

\begin{tabular}{|l|l|l|l|l|}
\hline \multirow{2}{*}{ Tahun } & \multicolumn{4}{|c|}{ Triwulan } \\
\cline { 2 - 5 } & I & II & II & IV \\
\hline 2011 & 0.23 & 0.20 & 0.40 & 0.20 \\
\hline 2012 & 0.17 & 1.21 & 1.34 & 1.19 \\
\hline 2013 & 1.17 & 1.41 & 1.36 & 1.15 \\
\hline 2014 & 0.46 & 0.03 & 0.20 & 0.08 \\
\hline 2015 & 0.53 & 0.78 & 0.80 & 0.77 \\
\hline 2016 & 0.99 & 1.03 & 0.98 & 0.95 \\
\hline 2017 & 0.65 & 0.71 & 0.82 & 0.51 \\
\hline 2018 & 0.86 & 0.92 & 0.77 & 0.43 \\
\hline
\end{tabular}

Sumber: $\underline{w w w . o j k . g o . i d}$

Berdasarkan tabel diatas dapat dilihat bahwa return on asset (ROA) berfluktuasi. Return On Asset (ROA) PT. BRI Syariah paling rendah terjadi pada tahun 2014 triwulan ke II sebesar 0.03 persen. Sedangkan Return On Asset (ROA) PT. BRI Syariah paling tinggi terjadi pada tahun 2013 triwulan ke II sebesar 1.41 persen, hal ini tidak sejalan dengan data kemampuan zakat.

3. Return On Equity (ROE)

Return On Equity (ROE) merupakan rasio untuk mengukur laba bersih sesudah pajak dengan modal sendiri. Rasio ini menunjukkan efesiensi penggunaan modal sendiri. Semakin tinggi rasio ini, semakin baik. Artinya posisi pemilik perusahaan semakin kuat. Return On Equity (ROE) merupakan salah satu alat utama investor yang paling sering digunakan dalam menilai suatu saham, dimana perkembangan mengenai Return On Equity (ROE) merupakan hal yang menarik untuk diikuti oleh para investor. Return On Equity (ROE) menggambarkan kemampuan perusahaan dalam memberikan keuntungan bagi pemilik nya. Return On Equity (ROE) menunjukkan keberhasilan atau kegagalan pihak manajemen dalam memaksimumkan tingkat hasil pengembalian investasi pemegang saham dan menekankan pada hasil pendapatan sehubungan dengan jumlah yang di investasikan. 


\section{Tabel 4}

\section{Return On Equity (ROE) Periode 2011-2018} (dalam persen)

\begin{tabular}{|c|c|c|c|c|}
\hline \multirow{2}{*}{ Tahun } & \multicolumn{4}{|c|}{ Triwulan } \\
\cline { 2 - 5 } & I & II & III & IV \\
\hline 2011 & 1.23 & 1.52 & 3.18 & 1.19 \\
\hline 2012 & 1.41 & 9.98 & 11.40 & 10.41 \\
\hline 2013 & 18.63 & 14.81 & 13.16 & 10.20 \\
\hline 2014 & 4.07 & 0.24 & 0.49 & 0.44 \\
\hline 2015 & 6.07 & 7.16 & 6.71 & 6.33 \\
\hline 2016 & 7.51 & 7.89 & 7.51 & 7.40 \\
\hline 2017 & 5.49 & 6.01 & 6.90 & 4.10 \\
\hline 2018 & 6.92 & 6.37 & 4.87 & 2.49 \\
\hline
\end{tabular}

Sumber: www.ojk.go.id

Berdasarkan data diatas dapat dilihat bahwa Return On Equity (ROE) berfluktuasi. PT. BRI Syariah mengalami Return On Equity (ROE) paling rendah terjadi pada tahun 2014 triwulan II sebesar 0.24 persen. Sedangkan Return On Equity (ROE) paling tinggi terjadi pada tahun 2013 triwulan I.

4. Biaya Operasional per Pendapatan Operasional (BOPO)

Biaya Operasional per Pendapatan Operasional (BOPO) adalah kelompok rasio yang mengukur efesien dan efektivitas operasional suatu perusahaan dengan jalur membandingkan satu terhadap lainnya. Berbagai angka pendapatan dan pengeluaran dari laporan rugi lab dan terhadap angka-angka dalam neraca.

Rasio beban operasional adalah perbandingan antara biaya operasional dan pendapatan operasional. Rasio beban operasional digunakan untuk mengukur tingkat efesiensi dan kemampuan bank dalam melakukan kegiatan operasi. Semakin rendah BOPO berarti semakin sefesien bank tersebut dalam mengendalikan biaya operasionalnya, dengan adanya efesiensi beban maka keuntungan yang diperoleh bank akan semakin baik.

Tabel 5

Biaya Operasional per Pendapatan Operasional (BOPO) (dalam persen)

\begin{tabular}{|c|c|c|c|c|}
\hline \multirow{2}{*}{ Tahun } & \multicolumn{4}{|c|}{ Triwulan } \\
\cline { 2 - 5 } & I & II & III & IV \\
\hline 2011 & 101.38 & 100.30 & 98.56 & 99.25 \\
\hline 2012 & 99.15 & 91.16 & 89.95 & 86.63 \\
\hline 2013 & 85.54 & 87.55 & 80.80 & 83.23 \\
\hline 2014 & 92.43 & 99.84 & 97.35 & 99.14 \\
\hline 2015 & 96.13 & 93.84 & 93.97 & 93.79 \\
\hline 2016 & 90.70 & 90.41 & 90.99 & 91.33 \\
\hline 2017 & 93.67 & 92.78 & 92.19 & 95.24 \\
\hline 2018 & 90.75 & 89.92 & 91.49 & 95.32 \\
\hline
\end{tabular}

Sumber: www.ojk.go.id 
259 | Pengaruh Kinerja Keuangan Terhadap Kemampuan Membayar Zakat PT. BRI Syariah Periode 2011 - 2018

Berdasarkan tabel diatas dapat dilihat bahwa Biaya Operasional per Pendapatan Operasional (BOPO) berfluktuasi. PT. BRI Syariah menghasilkan Biaya Operasional per Pendapatan Operasional (BOPO) paling rendah pada tahun 2013 triwulan III. Sedangkan Biaya Operasional per Pendapatan Operasional (BOPO) paling tinggi terjadi pada tahun 2011 triwulan I.

Hasil Analisis Statistik Deskriptif

Berikut ini hasil dari uji analisis statistik deskriptif sebagai berikut:

Tabel 6

Hasil Uji Statistik Deskriptif

Descriptive Statistics

\begin{tabular}{|l|r|r|r|r|r|r|}
\hline & \multicolumn{1}{|c|}{$\mathrm{N}$} & Minimum & Maximum & \multicolumn{2}{|c|}{ Mean } & Std. Deviation \\
\cline { 2 - 7 } & Statistic & Statistic & Statistic & Statistic & Std. Error & \multicolumn{1}{c|}{ Statistic } \\
\hline Roa & 32 & .03 & 1.71 & .7450 & .07666 & .43363 \\
Roe & 32 & .24 & 18.63 & 6.3153 & .77237 & 4.36917 \\
Bopo & 32 & 80.80 & 101.38 & 92.9619 & .88513 & 5.00705 \\
Zakat & 32 & 60 & 4599 & 1984.36 & 253.033 & 1431.373 \\
Valid N & 32 & & & & & \\
(listwise) & & & & & & \\
\hline
\end{tabular}

Sumber: Hasil Output SPSS Versi 23, data diolah

Berdasarkan Tabel 6 bahwa jumlah (N) sebanyak 32. Rata-rata kemampuan membayar zakat sebesar 1984,36, nilai minimum kemampuan membayar zakat sebesar 60, nilai maksimum kemampuan membayar zakat 4599 dan nilai standar kemampuan membayar zakat sebesar 1431,373. Rata-rata Return On Asset (ROA) sebesar 0,7450, nilai minimum Return On Asset (ROA) sebesar 0,03, nilai maksimum Return On Asset (ROA) sebesar 1,71 dan nilai standar Return On Asset (ROA) sebesar 0,43363. Rata-rata Return On Equity (ROE) sebesar 6,3153, nilai minimum Return On Equity (ROE) sebesar 0,24, nilai maksimum Return On Equity (ROE) sebesar 18,63, standar Return On Equity (ROE) sebesar 4,36917. Rata-rata Biaya Operasional per Pendapatan Operasional (BOPO) sebesar 92,9619, nilai minimum Biaya Operasional per Pendapatan Operasional (BOPO) sebesar 80,80, nilai maksimum Biaya Operasional per Pendapatan Operasional (BOPO) sebesar 101,8, standar Biaya Operasional per Pendapatan Operasional (BOPO) sebesar 5,00705. 


\section{Uji Asumsi Klasik}

\section{Uji Normalitas}

Hasil uji normalitas sebagai berikut:

Tabel 7

Hasil Uji Normalitas

One-Sample Kolmogorov-Smirnov Test

\begin{tabular}{|lc|r|}
\hline & & \multicolumn{2}{|c|}{$\begin{array}{c}\text { Unstandardized } \\
\text { Residual }\end{array}$} \\
\hline $\mathrm{N}$ & Mean & 32 \\
Normal & Std. & .0000000 \\
Parameters & Deviation & 781.10674852 \\
a,b & Absolute & .130 \\
Most & Positive & .130 \\
Extreme & Negative & -.119 \\
Differences & & .130 \\
Test Statistic & & .1840 \\
Asymp. Sig. (2-tailed) &
\end{tabular}

Sumber: Hasil pengolahan data SPSS 23

Berdasarkan tabel uji normalitas dengan Kolmogrov-Smirnov diatas dapat diketahui bahwa masing-masing variabel berdistribusi normal, hal ini dapat dilihat dari nilai signifikan (Asymp. Sig. 2-tailed) o,184 yang lebih besar dari 0,05. Jadi dapat disimpulkan bahwa semua variabel berdistribusi normal, sehingga dapat dilakukan penelitian selanjutnya.

\section{Uji Multikolineritas}

Hasil uji multikolinieritas sebagai berikut:

\section{Tabel 8}

\section{Hasil Uji Multikolinearitas}

\begin{tabular}{|c|c|c|c|c|c|c|c|c|}
\hline Ber & \multicolumn{8}{|c|}{ Coefficients $^{a}$} \\
\hline $\begin{array}{l}\text { das } \\
\text { ark }\end{array}$ & \multirow[b]{2}{*}{ Model } & \multicolumn{2}{|c|}{$\begin{array}{l}\text { Unstandardized } \\
\text { Coefficients }\end{array}$} & \multirow{2}{*}{$\begin{array}{l}\text { Standardized } \\
\text { Coefficients } \\
\text { Beta } \\
\end{array}$} & \multirow[b]{2}{*}{$\mathrm{t}$} & \multirow[b]{2}{*}{ Sig. } & \multicolumn{2}{|c|}{$\begin{array}{l}\text { Collinearity } \\
\text { Statistics }\end{array}$} \\
\hline & & $\mathrm{B}$ & Std. Error & & & & Tolerance & VIF \\
\hline dil & (Constant) & -32.505 & 113.524 & & -.286 & .777 & & \\
\hline hasi & roa & 1.360 & 1.318 & .342 & 1.031 & .311 & .282 & 3.540 \\
\hline l uji & roe & .125 & .332 & .151 & .377 & .709 & .194 & 5.167 \\
\hline mul & bopo & 9.697 & 24.817 & .146 & .391 & .699 & .222 & 4.502 \\
\hline
\end{tabular}

tiko a. Dependent Variable: zakat

Sumber: Hasil pengolahan data SPSS 23, data diolah

linearitas diatas, nilai VIF variabel Return On Asset (ROA) 3,540, Return On Equity (ROE) 
261 | Pengaruh Kinerja Keuangan Terhadap Kemampuan Membayar Zakat PT. BRI Syariah Periode 2011 - 2018

5,167 dan Biaya Operasional per Pendapatan Operasional (BOPO) 4,502 lebih kecil dari 10,00. Sehingga dapat disimpulkan bahwa keempat variabel diatas bebas dari multikolinearitas.

\section{Uji Heteroskedastisitas}

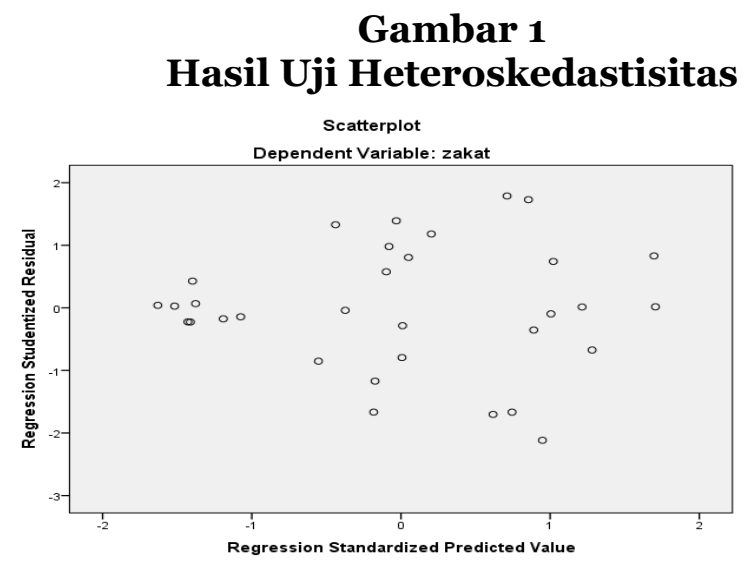

Sumber: Hasil pengolahan data SPSS 23, data diolah.

Berdasarkan gambar diatas terlihat titik-titik menyebar secara acak, tidak membentuk sebuah pola yang jelas, serta tersebar baik diatas maupun dibawah angka o pada sumbu Y. Hal ini berarti tidak terjadi heteroskedastisitas pada model regresi. Sehingga model regresi ini layak dipakai.

\section{Uji Autokorelasi}

Data yang digunakan untuk mengestimasi model regresi linier merupakan dara time series maka diperlukan asumsi bebas autokolerasi. Guna memastikan apakah model regresi linear terbebas dari autokolerasi, dapat menggunakan metode Durbin-Watson hipotesis. Hasil uji autokorelasi sebagai berikut:

Tabel 9

Hasil Uji Autokorelasi

Model Summaryb

\begin{tabular}{|r|r|r|r|r|r|}
\hline Model & $\mathrm{R}$ & R Square & $\begin{array}{c}\text { Adjusted R } \\
\text { Square }\end{array}$ & $\begin{array}{c}\text { Std. Error of } \\
\text { the Estimate }\end{array}$ & $\begin{array}{l}\text { Durbin- } \\
\text { Watson }\end{array}$ \\
\hline $1.88^{2}$ & .702 & .670 & 821.887 & 2.055 \\
\hline
\end{tabular}

a. Predictors: (Constant), bopo, roe, roa

b. Dependent Variable: zakat

\section{Sumber: Hasil pengolahan data SPSS 23, data diolah}

Berdasarkan tabel diatas dapat diketahui bahwa nilai DW adalah 2,055. Kemudian nilai signifikansi o,o5 dan jumlah data $32, \mathrm{k}=3$. diperoleh dl sebesar 1,244, dan du sebesar 1,650. Sehingga dapat disimpulkan bahwa tidak terjadi 
autokorelasi dalam model regresi penelitian ini karena $\mathrm{du}<\mathrm{dw}<4-\mathrm{du}$ atau 1,650 $<2,055<4-1,650$.

\section{Uji Hipotesis}

\section{a. Uji t}

Uji t digunakan untuk mengetahui model regresi variabel ROA, ROE, BOPO secara parsial terhadap kemampuan membayar zakat. Hasil uji t sebagai berikut:

\section{Tabel 10}

\section{Hasil Uji t}

Coefficients $^{\mathbf{a}}$

\begin{tabular}{|c|c|c|c|c|c|}
\hline \multirow[b]{2}{*}{ Model } & \multicolumn{2}{|c|}{$\begin{array}{c}\text { Unstandardized } \\
\text { Coefficients }\end{array}$} & \multirow{2}{*}{$\begin{array}{c}\text { Standardized } \\
\text { Coefficients }\end{array}$} & \multirow[b]{2}{*}{$\mathrm{t}$} & \multirow[b]{2}{*}{ Sig. } \\
\hline & $\bar{B}$ & Std. Error & & & \\
\hline 1 (Constant) & 20017.970 & 7090.121 & & 2.823 & .009 \\
\hline Roa & 5467.440 & 1696.170 & 1.656 & 3.223 & .003 \\
\hline Roe & -548.642 & 145.410 & -1.675 & -3.773 & .001 \\
\hline Воро & -200.534 & 70.162 & -.701 & -2.858 & .008 \\
\hline
\end{tabular}

a. Dependent Variable: zakat

Sumber: Hasil pengolahan data SPSS 23, data diolah

1) Pengujian koefisien variabel Return On Asset (ROA)

i. Merumuskan hipotesis

Ho : Return On Asset (ROA) secara parsial tidak berpengaruh terhadap kemampuan membayar zakat

Ha : Return On Asset (ROA) secara parsial berpengaruh terhadap kemampuan membayar zakat

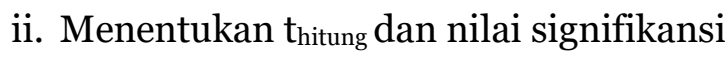

Dari output di daat thitung sebesar 3,223

iii. Menentukan $t_{\text {tabel }}$

$t_{\text {tabel }}$ dapat dilihat pada tabel statistik pada signifikansi 0,05 dengan derajat kebebasan $\mathrm{df}=\mathrm{n}-\mathrm{k}-1$ atau 32-3-1=28, hasil diperoleh untuk $\mathrm{t}_{\text {tabel }}$ sebesar 1,701.

iv. Kriteria pengujian

Jika $t_{\text {hitung }}>t_{\text {tabel }}$ maka Ha diterima,

Jika $t_{\text {hitung }}<t_{\text {tabel }}$ maka Ha ditolak,

v. Kesimpulan

Nilai $t_{\text {hitung }}>t_{\text {tabel }}(3,223>1,701)$ maka Ha diterima atau variabel Return On Asset (ROA) secara parsial berpengaruh terhadap kemampuan membayar zakat.

JISFIM: Journal of Islamic Social Finance Management, Volume 1, No 2 Tahun 2020 http://jurnal.iain-padangsidimpuan.ac.id/index.php/JISFIM 
263 | Pengaruh Kinerja Keuangan Terhadap Kemampuan Membayar Zakat PT. BRI Syariah Periode 2011 - 2018

2) Variabel Retun On Equity (ROE)

Hipotesis:

Ho : Retun On Equity (ROE) secara parsial tidak berpengaruh terhadap kemampuan membayar zakat

Ha : Retun On Equity (ROE) secara parsial berpengaruh terhadap kemampuan membayar zakat

$t_{\text {hitung }}=-3,733 t_{\text {tabel }}=1,701$

maka $t_{\text {hitung }}>t_{\text {tabel }}=$ Ha diterima atau Retun On Equity (ROE) secara parsial berpengaruh negatif terhadap kemampuan membayar zakat.

3) Variabel Biaya Operasional per Pendapatan Operasional (BOPO)

Hipotesis:

Ho : Biaya Operasional per Pendapatan Operasional (BOPO) secara parsial tidak berpengaruh terhadap kemampuan membayar zakat

Ha : Biaya Operasional per Pendapatan Operasional (BOPO) secara parsial tidak berpengaruh terhadap kemampuan membayar zakat

$t_{\text {hitung }}=-2,858 t_{\text {tabel }}=1,701$

maka $t_{\text {hitung }}>t_{\text {tabe } 1}=$ Ha diterima atau Biaya Operasional per Pendapatan Operasional (BOPO) secara parsial berpengaruh negatif terhadap kemampuan membayar zakat.

Uji F

Uji F digunakan untuk menunjukkan apakah semua variabel bebas atau insependen mempunyai pengaruh secara bersama-sama terhadap variabel dependen. Hasil uji F sebagai berikut:

\section{Tabel 11}

\section{Hasil Uji F}

ANOVAa

\begin{tabular}{|l|c|r|r|l|l|}
\hline Model & $\begin{array}{c}\text { Sum of } \\
\text { Squares }\end{array}$ & df & Mean Square & F & Sig. \\
\hline 1 Regression & 44599691.461 & 3 & 14866563.820 & 22.008 &. .000 $^{\mathrm{b}}$ \\
Residual & 18913960.330 & 28 & 675498.583 & & \\
Total & 63513651.791 & 31 & & & \\
\hline
\end{tabular}

a. Dependent Variable: zakat

b. Predictors: (Constant), bopo, roe, roa

Sumber: Hasil pengolahan SPSS 23, data diolah

JISFIM: Journal of Islamic Social Finance Management, Volume 1, No 2 Tahun 2020 http://jurnal.iain-padangsidimpuan.ac.id/index.php/JISFIM 
Hipotesis:

$\mathrm{H}_{\mathrm{O}}$ : Return On Asset (ROA), Return On Equity (ROE) dan Biaya Operasional per Pendapatan Operasional (BOPO) secara bersam-sama tidak berpengaruh terhadap kemampuan membayar zakat.

$\mathrm{H}_{\mathrm{a}}$ : Return On Asset (ROA), Return On Equity (ROE) dan Biaya Operasional per Pendapatan Operasional (BOPO) secara bersam-sama berpengaruh terhadap kemampuan membayar zakat.

Dari output diatas diperoleh $\mathrm{F}_{\text {hitung }}$ sebesar 22,008

$\mathrm{F}_{\text {tabel }}$ dengan tingkat signifikan o,o5 dengan df 1 (jumlah - 1) 2, df 2 (n-k-1) atau 32$3^{-1}=28$, maka $\mathrm{F}_{\text {tabel }}=2,95$

Kriteria:

jika $F_{\text {hitung }}>F_{\text {tabel }}$ maka tabel Ha diterima

kesimpulan:

$\mathrm{F}_{\text {hitung }}>\mathrm{F}_{\text {tabel }}$ atau 20,008 $>$ 2,95 atau Return On Asset (ROA), Return On Equity (ROE) dan Biaya Operasional per Pendapatan Operasional (BOPO) secara bersamsama berpengaruh terhadap kemampuan membayar zakat.

\section{Uji Koefesien Determinasi R Square ( $\left.\mathbf{R}^{2}\right)$}

Hasil uji koefisien determinasi sebagai berikut:

Tabel 11

Hasil Uji R Square

Model Summary

\begin{tabular}{|l|r|r|r|r|}
\hline Model & $\mathrm{R}$ & \multicolumn{1}{c|}{ R Square } & $\begin{array}{c}\text { Adjusted R } \\
\text { Square }\end{array}$ & $\begin{array}{c}\text { Std. Error of the } \\
\text { Estimate }\end{array}$ \\
\hline 1 &, $88^{\mathrm{a}}$ &, 702 &, 670 & 821,887 \\
\hline
\end{tabular}

a. Predictors: (Constant), BOPO, ROE, ROA

Dependent Variable: zakat

Sumber: Hasil pengolahan data SPSS 23, data diolah

Berdasarkan hasil diatas dapat diketahui nilai $\mathrm{R}^{2}$ sebesar 0,641 artinya persentase sumbangan pengaruh Return On Asset (ROA), Return On Equity (ROE) dan Biaya Operasional per Pendapatan Operasinal (BOPO) berpengaruh terhadap kemampuan membayar zakat sebesar 70,2\%, sedangkan sisanya sebesar 29,8\% dipengaruhi oleh variabel diluar penelitian.

\section{Hasil Uji Regresi Linear Berganda}

JISFIM: Journal of Islamic Social Finance Management, Volume 1, No 2 Tahun 2020 http://jurnal.iain-padangsidimpuan.ac.id/index.php/JISFIM 
265 | Pengaruh Kinerja Keuangan Terhadap Kemampuan Membayar Zakat PT. BRI Syariah Periode 2011 - 2018

Hasil regresi linear berganda adalah sebagai berikut:

Tabel 13

Hasil Uji Regresi Linear Berganda

Coefficients $^{\mathbf{a}}$

\begin{tabular}{|l|c|c|c|r|r|}
\hline \multirow{2}{*}{ Model } & \multicolumn{2}{|c|}{$\begin{array}{c}\text { Unstandardized } \\
\text { Coefficients }\end{array}$} & $\begin{array}{c}\text { Standardized } \\
\text { Coefficients }\end{array}$ & $\mathrm{t}$ & Sig. \\
\cline { 2 - 6 } & \multicolumn{1}{|c|}{ B } & Std. Error & Beta & & \\
\hline (Constant) & 20017.970 & 7090.121 & & 2.823 & .009 \\
Roa & 5467.440 & 1696.170 & 1.656 & 3.223 & .003 \\
Roe & -548.642 & 145.410 & -1.675 & -3.773 & .001 \\
Bopo & -200.534 & 70.162 & -.701 & -2.858 & .008 \\
\hline
\end{tabular}

a. Dependent Variable: zakat

Sumber: Hasil pengolahan data SPSS 23, data diolah

Persamaan regresi linear berganda dengan 3 variabel independen sebagai berikut:

$\mathrm{ZK}_{\mathrm{i}}=\mathrm{a}+\mathrm{b}_{1} \mathrm{ROA}_{\mathrm{i}}+\mathrm{b}_{2} \mathrm{ROE}_{\mathrm{i}}+\mathrm{b}_{3} \mathrm{BOPO}_{\mathrm{i}}+\mathrm{e}$

Keterangan:

ZK : nilai prediksi variabel dependen (kemampuan membayar zakat)

a : Konstanta, yaitu nilai ZK, ROA, ROE dan BOPO = o

$b_{1} b_{2} b_{3}$ : koefisien regresi, yaitu nilai peningkatan atau penurunan variabel Zk yang didasarkan variabel ROA, ROE dan BOPO

ROA : Return On Asset

ROE : Retuen On Equity

BOPO : Biaya Operasional per Pendapatan Operasional (BOPO)

Berdasarkan output:

$\mathrm{Zk}=20017,970+5467,440 \mathrm{ROA}+-548,440 \mathrm{ROE}+-200,534 \mathrm{BOPO}$

Artinya:

a. Nilai konstanta sebesar 20017,970 artinya apabila Return On Asset (ROA), Return On Equity (ROE) dan Biaya Operasional per Pendapatan Operasional (BOPO) nilainya o, maka kemampuan membayar zakat Rp. 20017,970.

b. Nilai variabel Return On Asset (ROA) yaitu 5467,440 artinya apabila ROA meningkat 1 satuan maka kemampuan membayar zakat meningkat sebesar 54,67440 persen. Koefisien bernilai positif artinya terjadi hubungan positif antara Return On Asset (ROA) dengan kemampuan membayar zakat. Return On Asset 
(ROA) yang semakin meningkat maka kemampuan membayar zakat juga akan semakin meningkat. Maka hal ini sejalan dengan teori.

c. Nilai variabel Return On Equity (ROE) yaitu $-548,410$ artinya apabila ROE meningkat 1 satuan maka kemampuan membayar zakat menurun sebesar 5,484 persen. koefisien bernilai negatif artinya tidak terjadi hubungan yang positif antara Return On Equity (ROE) dengan kemampuan membayar zakat. Return On Equity (ROE) yang semakin meningkat maka kemampuan membayar zakat juga semakin meningkat. maka hal ini tidak sebanding dengan teori.

d. Nilai variabel BOPO yaitu $-200,534$ artinya apabila BOPO meningkat 1 satuan maka kemampuan kemampuan membayar zakat menurun sebesar 2,005 persen. Koefisien bernilai negatif artinya tidak terjadi hubungan positif antara BOPO dengan kemampuan membayar zakat. BOPO yang semakin meningkat maka kemampuan membayar zakat juga semakin meningkat. Maka hal ini tidak sebanding dengan teori.

Berdasarkan hasil uji hipotesis menunjukkan bahwa Return On Asset (ROA) berpengaruh terhadap kemampuan membayar zakat. Hal ini dibuktikan dengan hasil statistik uji hipotesis yang diperoleh Return On Asset (ROA) menunjukkan nilai t hitung sebesar 3,223 sedangkan t tabel 1,699. Hal ini dapat disimpulkan bahwa Return On Asset (ROA) berpengaruh terhadap kemampuan membayar zakat.

Tingkat ROA yang semakin tinggi mengindikasikan semakin besar pula tingkat keuntungan yang dicapai bank dengan demikian maka meningkat pula pengeluaran zakat bank. Hal tersebut perlu suatu perencanaan yang matang dalam manajemen dana perbankan. Hal ini berkaitan dengan Teori Keagenan yang menyatakan bahwa pada perusahaan terdapat dua pihak yang saling berinteraksi, yaitu antara pemegang saham/pemilik dan manajemen/manajer perusahaan.

Return On Asset (ROA) memiliki pengaruh yang signifikan terhadap kemampuan pengeluaran zakat terhadap bank syariah berarti jika ROA tinggi maka akan berpengaruh terhadap kemampuan zakat bank syariah yang meningkat. Jika ROA tinggi, akan berdampak pada pendapatan laba sebelum pajak pada bank syariah akan meningkat dan kemampuan zakat pun akan meningkat. Begitupun sebaliknya, jika ROA rendah, akan berpengaruh terhadap kemampuan zakat yang semakin menurun. Hal ini terjadi karena jika ROA rendah, akan berdampak pada pendapatan laba sebelum pajak pada bank syariah yang menurun dan kemampuan zakat pun akan menurun.

Hasil penelitian ini sejalan dengan penelitian sebelumnya yang dilakukan oleh, Filzah Arifah Nurdiani memberikan hasil bahwa Return On Asset (ROA) berpengaruh positif signifikan terhadap pembayaran zakat. Berdasarkan teori dan bukti empiris http://jurnal.iain-padangsidimpuan.ac.id/index.php/JISFIM 
267 | Pengaruh Kinerja Keuangan Terhadap Kemampuan Membayar Zakat PT. BRI Syariah Periode 2011 - 2018

tentang pengaruh Return On Asset (ROA) terhadap kemampuan membayar zakat, maka dapat disimpulkan bahwa Return On Asset (ROA) berpengaruh terhadap kemampuan membayar zakat. Sedangkan hasil penelitian yang dilakukan oleh Ani Sumiati yang memberikan hasil bahwa profitabilitas tidak berpengaruh terhadap pengeluaran zakat.

Jadi, dapat disimpulkan peneliti dalam hal ini menyatakan Return On Asset (ROA) berpengaruh terhadap kemampuan membayar zakat PT. BRI Syariah.

Berdasarkan hasil uji hipotesis menunjukkan bahwa Return On Equity (ROE) berpengaruh negatif terhadap kemampuan membayar zakat. Hal ini dibuktikan dengan hasil statistik uji hipotesis yang diperoleh Return On Equity (ROE) menunjukkan nilai t hitung sebesar $-3,773$ sedangkan t tabel 1,699. Hal ini dapat disimpulkan bahwa Return On Equity (ROE) berpengaruh negatif signifikan terhadap kemampuan membayar zakat.

Semakin tinggi tingkat ROE semakin tinggi pula tingkat laba yang dihasilkan karena penambahan dalam modal kerja suatu perusahaan dapat digunakan untuk membiayai operasi perusahaan yang hasilnya dapat menghasilkan laba kembali. Sehingga semakin tinggi rasio ROE akan berdampak pada semakin tinggi pula zakat yang akan dikeluarkan oleh perusahaan. Hal tersebut dapat terjadi karena zakat merupakan tanggung jawab dan kewajiban setiap perusahaan. Dengan melakukan tanggung jawab jawab sosial yang bertujuan kepada kegiatan keislaman maupun dengan niat untuk membantu sesame umat muslim dan untuk meringankan beban perekonomian. Hal ini berimplikasi terhadap masyarakat akan mempercayai perbankan syariah benar-benar menjalankan bisnisnya sesuai dengan ketentuan syariah Islam.

Hasil pengkajian ini membantu teori yang mengatakan sebenarnya zakat memiliki kekerabatan dengan keuntungan. Rancangan keuntungan pada akuntansi syariah sangat dibutuhkan untuk menetapkan besarnya zakat yang perlu ditunaikan. Teori ini pula menjelaskan sesungguhnya entitas senantiasa diperbolehkan untuk mencari keuntungan namun tetap dalam landasan syariah dan sejalan dengan itu sebagian keuntungan atau laba yang diperoleh diberikan sebagai zakat perusahaan.

Hasil penelitian ini sejalan dengan penelitian terdahulu yang dilakukan oleh Fitria Liana, ROE berpengaruh signifikan terhadap variabel defenden yaitu zakat perusahaan. Sedangkan hasil penelitian yang dilakukan oleh Ani Sumiyati yang berjudul menyatakan dalam penelitiannya, Profitabilitas tidak berpengaruh terhadap pengeluaran zakat dan ukuran perusahaan tidak mampu memoderasi pengaruh profitabilitas terhadap pengeluaran zakat. Jadi, dapat disimpulkan peneliti dalam hal 
ini menyatakan bahwa Return On Equity (ROE) berpengaruh negatif terhadap kemampuan membayar zakat PT. BRI Syariah.

Berdasarkan hasil uji hipotesis menunjukkan bahwa Biaya Opersional per Pendapatan Operasional (BOPO) tidak berpengaruh terhadap kemampuan membayar zakat. Hal ini dibuktikan dengan hasil statistik uji hipotesis yang diperoleh Biaya Opersional per Pendapatan Operasional (BOPO) menunjukkan nilai t hitung sebesar 2,858 sedangkan t tabel 1,699. Hal ini dapat disimpulkan bahwa Biaya Opersional per Pendapatan Operasional (BOPO) berpengaruh negatif terhadap kemampuan membayar zakat.

Meneladani Surat Edaran Bank Indonesia yang dikeluarkan taanggal 31 Mei 2004 No. 6/23/DPNP dalam lampiran Id, Biaya operasional per Pendapatan Operasional (BOPO) untuk memperkirakan kesanggupan manajemen bank dalam mengelola biaya operasional terhadap pendapatan operasional. Jika semakin rendah rasio BOPO bermakna semakin berdaya guna biaya operasional yang dikeluarkan bank yang bersangkutan sehingga potensial suatu bank syariah dalam perihal bermasalah semakin kecil. Dengan demikian kedayagunaan operasi suatu bank yang diproksikan oleh rasio BOPO akan mempengaruhi kinerja suatu bank. Sehingga setiap perusahaan harus memaksimalkan kinerja agar perusahaan dapat meningkatkan pengeluaran zakat. Setiap peningkatan BOPO akan berpengaruh pada kurangnya keuntungan sebelum pajak yang cukup akhirnya tentu menurunkan tingkat rentabilitas bank.

Adapun penelitian yang juga dilakukan oleh Winda Tri Jayanti, Siti Khairani, Raisa Pratiwi menyatakan dalam peneliannya bahwa BOPO tidak berpengaruh terhadap zakat. Sedangkan dalam penelitian yang dilakukan oleh Fitri Liana yang menyatakan dalam penelitiannya bahwa BOPO berpengaruh positif terhadap pengeluaran zakat perusahaan.

Jadi, dapat disimpulkan peneliti dalam penelitian ini bahwa Biaya Operasional

per Pendapatan Operasional (BOPO) berpengaruh negatif terhadap kemampuan membayar zakat PT. BRI Syariah.

\section{KESIMPULAN}

Secara parsial Return On Asset (ROA) berpengaruh terhadap kemampuan membayar zakat PT. BRI Syariah periode 2011-2018 dilihat dari nilai $t_{\text {hitung }}$ sebesar 3,223 $>t_{\text {tabel }}$ 1,701 maka Ho ditolak dan Ha diterima artinya terdapat pengaruh antara Return On Asset (ROA) dengan kemampuan membayar zakat. Secara parsial Return On Equity (ROE) berpengaruh negatif terhadap kemampuan membayar zakat PT. BRI Syariah periode 2011-2018 dilihat dari nilai $t_{\text {hitung }}$ sebesar -3,773 $>t_{\text {tabel }}$ 1,701. Maka Ha diterima artinya terdapat pengaruh antara Return On Equity (ROE) terhadap kemampuan http://jurnal.iain-padangsidimpuan.ac.id/index.php/JISFIM 
269 | Pengaruh Kinerja Keuangan Terhadap Kemampuan Membayar Zakat PT. BRI Syariah Periode 2011 - 2018

membayar zakat. Secara parsial Biaya Operasional per Pendapatan Operasional (BOPO) tidak berpengaruh terhadap kemampuan membayar zakat PT. BRI Syariah periode 20112018 dilihat dari nilai $t_{\text {hitung }}$ sebesar $-2,858>t_{\text {tabel }}$ 1,701. Maka Ha diterima artinya terdapat pengaruh antara Biaya Operasional per Pendapatan Operasional (BOPO) terhadap kemampuan membayar zakat. Secara simultan (bersama-sama) Return On Asset (ROA), Return On Equity (ROE) dan Biaya Operasional per Pendapatan Operasional (BOPO) berpengaruh terhadap kemampuan membayar zakat PT. BRI Syariah periode 2011-2018 dilihat dari besar $F_{\text {hitung }}$ sebesar 22,008 $>F_{\text {tabel }}$ 2,95 maka Ho ditolak dan Ha diterima. Jadi dapat disimpulkan bahwa secara simultan Return On Asset (ROA), Return On Equity (ROE) dan Biaya Operasional per Pendapatan Operasional (BOPO) berpengaruh terhadap kemampuan membayar zakat.

\section{DAFTAR PUSTAKA}

Al-Zuhayly, W. (2000). Zakat Kajian Berbagai Mazhab. PT Remaja Rosdakarya Offset.

Departemen Agama RI. (2014). Al-Qur'an dan Terjemahnya. Halim Publishing \& Distributing.

Hafidhuddin, D. (2002). Zakat dan Perekonomian Modern. Gema Insani Pers.

Khasanah, U. (2010). Manajemen Zakat Modern. UIN MALIKI PRESS.

Kuncoro, M. (2009). Metode Riset Untuk Bisnis dan Ekonomi. Erlangga.

Liana, F. (2018). Pengaruh Rasio Profitabilitas terhadap pengeluaran Zakat Perusahaan:

Studi kasus pada Bank Umum Syariah di Indonesia periode 2012-2016

[Undergraduate, Universitas Islam Negeri Maulana Malik Ibrahim]. http://etheses.uin-malang.ac.id/12725/

Muhamad. (2008). Metodologi Penelitian Ekonomi Islam. Raja Grafinfo Persada.

Nurhayati, S. (2014). Akuntansi Syariah di Indonesia. Salemba Empat.

Rizal, A., Fauziyah, N. E., Ma’ruf, A., \& Susilo, A. (2020). INTEGRATING ZAKAH AND WAQF FOR DEVELOPING ISLAMIC ECONOMIC BOARDING SCHOOL (IEBS) PROJECT IN INDONESIA. Journal of Islamic Economics and Philanthropy, 3(02).

Setiawan, A. R. (2019). Studi analisis terhadap strategi penghimpunan zakat di Rumah Zakat [PhD Thesis]. UIN Walisongo.

Shihab, M. Q. (2002). Tafsir Al-Misbah. Lentera Hati.

JISFIM: Journal of Islamic Social Finance Management, Volume 1, No 2 Tahun 2020 http://jurnal.iain-padangsidimpuan.ac.id/index.php/JISFIM 
Sukmawati, E. (2018). Analisis Pengaruh Kinerja Keuangan terhadap Kemampuan Zakat pada Bank Umum Syariah di Indonesia Periode 2012-2016.

Tim Fokusmedia. (2012). Undang-undang Pengelolaan Zakat dan Wakaf. Fokus Media.

Tri Jayanti, W., Khairani, S., \& Pratiwi, R. (n.d.). Pengaruh Kinerja Keuangan terhadap Zakat Bank Umum Syariah yang Terdaftar di Bank Indonesia Periode 2010-2014.

Retrieved May 3, 2021, from https://core.ac.uk/display/35319443 http://jurnal.iain-padangsidimpuan.ac.id/index.php/JISFIM 